\title{
A DIESEL ENGINE CONVERTED INTO OTTO CYCLE ENGINE: THE INFLUENCE OF THE SPARK ADVANCE ON ITS PERFORMANCE AND ON NO EMISSIONS
}

\author{
B. L. N. Oliveira ${ }^{a}$, \\ E. F. Jaguaribe ${ }^{\mathrm{a}}$, \\ A. F.Bezerra ${ }^{a}$, \\ A. S. Rumão ${ }^{a}$, \\ and B. L. C. Queirogab \\ ${ }^{a}$ Universidade Federal do Paraíba \\ Departamento de Engenharia Mecânica \\ Jardim Cidade Universitária \\ CP. 58059-900, J. Pessoa, Paraíba, Brasil \\ beniltonluis@yahoo.com.br \\ ${ }^{\mathrm{b}}$ Universidade Federal do Paraíba \\ Departamento de Engenharia de Energias \\ Renováveis \\ Jardim Cidade Universitária \\ CP. 58059-900, J. Pessoa, Paraíba, Brasil. \\ Received: November 19, 2012 \\ Revised: December 29, 2012 \\ Accepted: January 29, 2013
}

\begin{abstract}
This paper analyzes the performance of a diesel engine converted into an Otto cycle engine and its Nitrogen dioxide emissions in terms of the spark advance variation. The tests were conducted on a Perkins diesel engine $1104 \mathrm{C}$ - 44TAG turbocharged, whose compression ratio was reduced to 9.33:1. After conversion the engine started operating with liquefied petroleum gas (LPG) and running just with stoichiometric mixtures. The tests have been limited to 10 to $40 \mathrm{~kW}$, always at $1800 \mathrm{rpm}$. During the experiments the ignition advance angle ranged from $5^{\circ}$ up to $27^{\circ}$ (BTDC), using the increment of $5^{\circ}$, whenever possible. Particularly at $40 \mathrm{~kW}$, the range of the ignition advance was $15^{\circ}$ to $20^{\circ}$. The results showed a significant influence of the spark advance angle on the fuel consumption, on the temperature and on the $\mathrm{NO}_{\mathrm{x}}$ emissions, as well as on the magnitude of the generated power.
\end{abstract}

Keywords: LPG. Spark Advance. $\mathrm{NO}_{\mathrm{x}}$ emissions. Performance of a diesel converted engine to an Otto cycle.

\section{NOMENCLATURE}

BTDC - Before the Top Dead Center ICE - Internal Combustion Engine SA - Spark Advanced LPG - Liquefied petroleum gas TDC -Top Dead Center

\section{Greek Symbols}

$\lambda$-air/fuel ratio

\section{INTRODUCTION}

The spark advance (SA) is one of the most influent physical parameters in any internal combustion engine (ICE). Incorrect spark timing can have a disastrous effect on the engine performance, affecting its thermal efficiency and the gas emission output.

Theoretically, the spark to combust the fuel/air mixture should occur exactly at top dead center (TDC), if the combustion happens instantaneously. In fact, the point of peak combustion pressure takes place when the piston is just beyond TDC. If the peak is too early and before TDC the pressure wave will retard the movement of the piston in its way toward the blast. As a result, it may cause detonation (knocking) which may damage the engine (Ferguson, 2001). On the other hand, if the point of peak combustion pressure is too late the wave will follow the piston in its descent, imposing some energy losses. It is fallacious to believe that the ideal point of peak combustion pressure occurs at the maximum pressure value. It is true that increasing the angle of spark advance enlarges the pressure inside the cylinder. However, it should be noted that different spark advance angles correspond to distinct pressure curves which are associated with negative work (during compression) and positive work (during expansion). This means that their summation varies from a minimum, going through a maximum value and falling down again. Therefore, the maximum pressure is not related to the ideal spark advance.

Theoretically, it is possible to determine the ideal spark advance angle computing the maximum useful work i.e. the maximum area under the pressure-volume diagram, which matchs with the point of maximum torque. In practice, the determination of the ideal spark advance angle 
requires a considerable number of experiments. One way is by fixing up the engine power and rpm, while choosing the ignition timing through an experimental process of trial and error. The fact that the ideal angle prevents the knocking and contributes to lower the fuel consumption contributes to the determination of the best option.

As already mentioned the spark advance may alter the exhausted gas emissions, especially of $\mathrm{NO}_{\mathrm{x}}$ $\left(\mathrm{NO}+\mathrm{NO}_{2}\right)$. These species are produced during the combustion process when the cylinder is submitted to high pressures and temperatures. In these conditions the nitrogen from the admitted air can react with oxygen to form Oxides of Nitrogen $\left(\mathrm{NO}_{\mathrm{x}}\right)$. There are several reasons for the excessive production of $\mathrm{NO}_{\mathrm{x}}$ such as: lean air/fuel mixture, high temperature intake air, overheated engine and also the excessive spark advance. The reactions to the formation of $\mathrm{NO}_{\mathrm{x}}$ species are highly endothermic, i.e., they occur at the expenses of a large amount of heat existing in the combustion chamber. In result it may produce an abrupt reduction of the engine performance (Martins, 2006).

Given the importance and trouble the $\mathrm{NO}_{\mathrm{x}}$ may cause the engine much literature has been published about the subject. Mustafi and Raine (2008) conducted a simulation using the Integrated Spark Ignition engine Simulation (ISIS) to study the performance and emission of $\mathrm{NO}_{\mathrm{x}}$ from a spark ignition engine as a function of crank angle, operating with biogas and "Powergas", (a synthetic gaseous fuel). The simulated results were compared with experimental temperature and exhaust gas data emissions, showing acceptable approximation. Alasfour (1998) analyzed the effect of the air/fuel ratio and ignition timing of a spark ignition engine, fueled with gasoline blended with $30 \%$ iso-butanol, in the emission of $\mathrm{NO}_{\mathrm{x}}$. The results showed that increasing the spark advance, in lean mixtures, it will have a $\mathrm{NO}_{\mathrm{x}}$ peak of emission. Tribbett et. al (2002) used a spark ignition engine having a removable dome head (RDH) with a compression ratio of $7: 1$, to study the effect of the spark advance in the temperature of exhaust gases, in internal pressure of the cylinder and in the knock limit. It was evident that there is an upper limit to the spark advance, which will produce detonation of the fuel, due also to the increased internal pressure of the cylinder. They also concluded that the temperature of the exhaust gases is smaller for greater advances and vice versa.

In all engine conversion it is always necessary to ensure the best performance and the low exhaust emission for the modified engine, running with the alternative fuel. Therefore, in our research group which converts Diesel engines into Otto cycle engines, the effect of the spark advance angle in the engine performance constitutes an ordinary activity, as this work intends to show (Ferraz, 2010; Oliveira, 2009; Queiroga, 2009; Rumão, 2008).

\section{METHODOLOGY}

To analyze the influence of the spark advance in fuel consumption and $\mathrm{NO}_{\mathrm{x}}$ emissions, some operating conditions were previously established:

1. The engine should run with stoichiometric air/gas (LPG) mixture at a fixed revolution, i. e. 1800 rpm, in order to guarantee low fuel consumption;

2. The compression ratio, was set at 9.33:1, even though it was noted, during the experiments, that a smaller rate would do better.

3. The engine should run without any sign of detonation.

Consequently, the maximum power produced was limited to $40 \mathrm{~kW}$, and the suitable spark advance angles used in the tentative and trial process went from $5^{\circ}$ to $27^{\circ}$ (for powers up to $30 \mathrm{~kW}$ ) with increment angle of $5^{\circ}$, applied whenever possible. For power ranging from $30 \mathrm{~kW}$ to $40 \mathrm{~kW}$ the suitable advance angles were situated between $15^{\circ}$ to $20^{\circ}$ (for angles above $20^{\circ}$, the engine presented the knocking effect and below $15^{\circ}$, the turbo compressor became overly hot). The trying experiments were stopped at the first sign of detonation noise. At this moment the spark advance angle was lowered $1^{\circ}$, and the essay repeated.

\section{EXPERIMENTS}

In all the tests a turbocharged diesel engine Perkins, converted into Otto cycle, was used. It was fueled with liquefied petroleum gas (LPG), having at the beginning the concentration of $55 \%$ propane and $45 \%$ butane. The original engine compression ratio of 18.2:1 was reduced, after conversion, to 9.33:1. An automatic feed system for gas, has allowed to keep the mixture close to stoichiometric $(\lambda=1.0)$. A throttle body with electronic governor, kept the engine speed fixed at $1800 \mathrm{rpm}$. To analyze the fuel consumption a gas flow meter was used, with instantaneous readings in $\mathrm{kg} / \mathrm{h}$. A vehicular gas analyzer helped to evaluate the amount of $\mathrm{NO}_{\mathrm{x}}$ and other pollutants emissions at the uncatalyzed exhaust tubing.

An electric dynamometer functioned in the evaluation of the performance of the converted engine running at different spark advance angles.

A type-K thermocouple placed on the exhaust pipe and connected to a digital thermometer, served to register the temperatures of the exhaust gases.

The fuel consumption in $\mathrm{kg} / \mathrm{h}$, was recorded for each experiment.

The engine operating time for the evaluation of each advance angle was about five minutes.

\section{RESULTS AND DISCUSSION}

Figure 1 shows the gas consumption in terms of the produced engine power, for six different spark advance angles. Figure 2 shows the behavior of $\mathrm{NO}_{\mathrm{x}}$ 
emission as a function of power and Fig. 3 presents temperature distribution curves as a function of power for different advance angles.

Note in Fig. 1, the larger the spark advance, the lower the fuel consumption, and the larger the power produced. The difference in consumption for $5^{\circ}$ and $27^{\circ}$ is $1.7 \mathrm{~kg} / \mathrm{h}$, at $20 \mathrm{~kW}$. It goes up to $3.09 \mathrm{~kg} / \mathrm{h}$, when the engine is producing $10 \mathrm{~kW}$.

As seen in Fig. 2, $\mathrm{NO}_{\mathrm{x}}$ emissions increase with the spark advance angle. The $\mathrm{NO}_{\mathrm{x}}$ emission at $27^{\circ}$, is almost 4 times larger than at $5^{\circ}$. This happens because pressure increases with the advance angle, and so does the temperature in the combustion chamber, enhancing the gas dissociation and the formation of $\mathrm{NO}_{\mathrm{x}}$.

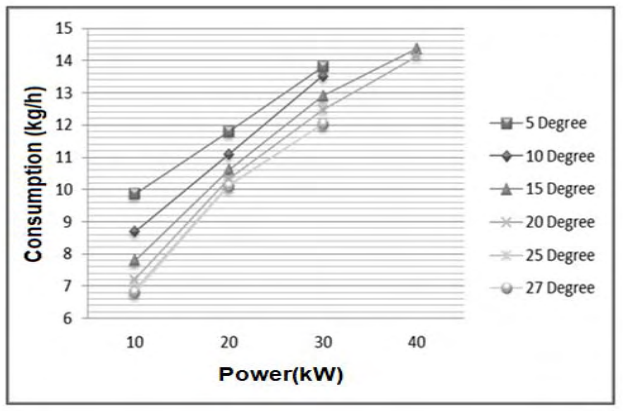

Figure 1. Effect of spark advance in fuel consumption.

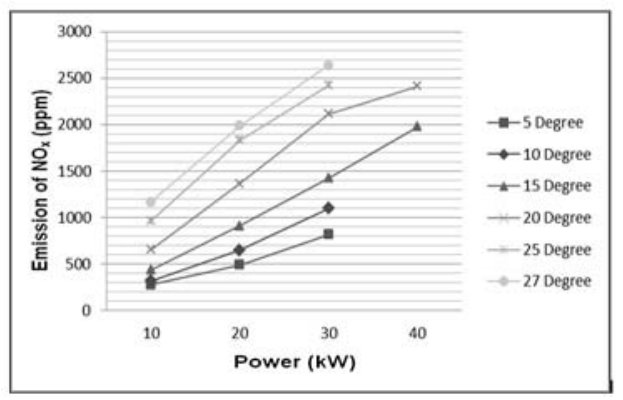

Figure 2. Influence of the spark advance in $\mathrm{NO}_{\mathrm{x}}$ emissions.

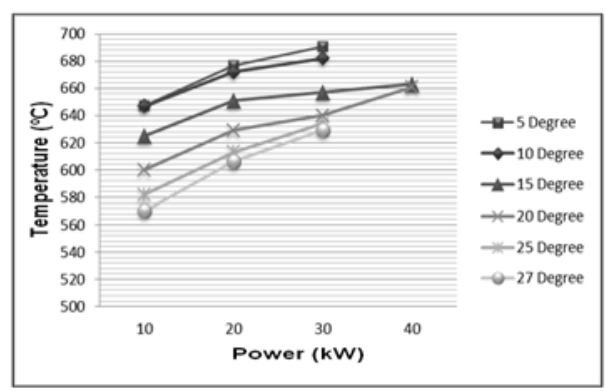

Figure 3. Exhaust gas temperature as a function of power for different values of spark advance.

It is observed from Fig. 3 that the gas temperature increases with power and decreases with the spark advance. For a given power the maximum temperature difference was $77^{\circ} \mathrm{C}$. As expected, it happened for the minimal examined power, and thus for the two extreme advance corresponding angles. At $30 \mathrm{~kW}$ the temperature difference fell to $62^{\circ} \mathrm{C}$. As explained, larger angles should reduce the gas temperature due to the gas dissociation process.

For powers above $30 \mathrm{~kW}$ the use of advance angle between $5^{\circ}$ to $10^{\circ}$, causes at the surface of the turbocharger as well as at the exhaust manifold an overheating process, showing an intense and bright red color, at $560{ }^{\circ} \mathrm{C}$.

\section{CONCLUSION}

Based on the analyzed data it is possible to reach the following conclusions:

1) There is a consistent connection between the spark advance angle of the converted engine and its fuel consumption: the larger the angle, the smaller the consumption.

2) Increasing the spark advance contributes to enlarge the production of $\mathrm{NO}_{\mathrm{x}}$ and then to decrease the temperature of the exhaust gas. Therefore, the use of catalysts may be required in some cases.

3) Adjusting the spark advance angle allows minimizing the fuel consumption.

4) To achieve higher powers it is necessary to reduce the spark advance angle, avoiding detonation. Making the engine run at $50 \mathrm{~kW}$ was possible by using rich mixtures $(\lambda=0.87)$ and the angle equal to $17^{\circ}$.

After reducing the compression ratio, new tests can be made for further continuing exploiting the influence of the advance angle on the converted engine performance.

\section{REFERENCE}

Alasfour, F. N., 1998, $\mathrm{NO}_{\mathrm{x}}$ Emission from a Spark Ignition Engine Using $30 \%$ Iso-ButanolGasoline Blend: part 2 - Ignition Timing, Applied Thermal Engineering, Pergamon, Vol. 18, No. 8, pp. 609-618.

Ferguson, C. R., 2001, Internal Combustion Engines: Applied Thermodynamics, John Wiley \& Sons, New York.

Ferraz, F. B., 2010, Conversão de um Motor Diesel com Bico Injetor no Interior da Tampa de Tuchos para Gás Liquefeito de Petróleo, Master Thesis, Universidade Federal da Paraíba, Paraíba, Brasil. (in Portuguese)

Martins, J., 2006, Motores de Combustão Interna, 3. Ed. Porto, Publindústria, Edições Técnicas. (in Portuguese)

Mustafi, N. N., and Raine, R. R., 2008, Application of Spark Ignition Engine Simulation Tool for Alternative Fuels, Journal of Engineering for Gas Turbines and Power, Vol. 130, No. 1, pp. 1280412808. 
Oliveira, B. L. N., 2009, Conversão de um Motor a Diesel para Operar Apenas com Gás Liquefeito de Petróleo, Master Thesis, Universidade Federal da Paraíba, Paraíba, Brasil. (in Portuguese)

Queiroga, B. L.C., 2009, Conversão de um Motor a Diesel para Álcool com Sistema Multiponto de Alimentação e de Injeção e Ignição Eletrônica, Master Thesis, Universidade Federal da Paraíba, Paraíba, Brasil. (in Portuguese)

Rumão, A. S., Desempenho de um Motor Diesel Estacionário Convertido para Gás Natural em Função de sua Taxa de Compressão, Master Thesis, Universidade Federal da Paraíba, Paraíba, Brasil. (in Portuguese)

Tribbett, E., Froehlich, E., and Bayer, L., 2002, Effects of Ignition Timing, Equivalence Ratio and Compression Ratio on RDH Engine Performance, Standford University. 